\title{
Informal Sector and Nigerian Economic Prospects: The Covid-19 Experience
}

\author{
Nnabuife Ezimma K., Okoli Ifeanyi .E. Nuel and Anugwu Clara Chika
}

\begin{abstract}
The informal sector is essential for economic growth. It is a key provider of jobs and income in emerging economies. But the crisis caused by the pandemic has had a significant impact on these economies. Therefore, this study investigates the impact of Covid-19 on the economic prospects of the informal sector of Nigeria and also proposes various strategies to support the sector. The study highlights some of the challenges facing the informal sector of Nigeria, such as institutional inadequacies, unsafe working conditions, poor enforcement and the non-participation of informal entrepreneurs in decision-making. The impact of Covid-19 is felt in different ways, which means that all the elements of total demand will be reduced. The study recommends that the government implement effective and cost-effective tax incentive packages to minimize the impact of corona virus pandemics on the informal sector. The government should also step down from paying taxes in critical areas in response to the crisis to support the informal sector and other businesses.
\end{abstract}

Index Terms - Informal sector, Covid-19, Economic prospects, Fiscal stimulus packages.

\section{INTRODUCTION}

The informal sector plays a key role in the economic structure of many developing countries, especially Nigeria. The informal sector refers to the part of the economy that does not fall within the scope of organized economic activities. Given that this sector is made up of many unorganized economic activities, such as trade, agriculture, construction, manufacturing, transport and services, businesses in this sector are an important form of production organization and a key provider of employment opportunities and income to populace. The International Labor Organization (ILO) (1999) estimates that the share of the urban labor force in the informal sector is the highest in sub-Saharan Africa and accounts for more than 50\% of urban employment in the two thirds of countries surveyed. This is an indication that informal activities in the sector are important in many African countries and possibly in developing countries. [28] claims that more than $61 \%$ of the world's active population works in the informal sector, with 85.8\% of employment in Africa in the informal sector and more than $65 \%$ of the active population in Nigeria belongs to the informal sector.

In Nigeria, in general, the contributions of the informal sector to the development of the economy in terms of job

Published on July 21, 2020

Nnabuife Ezimma K., Nnamdi Azikiwe University, Nigeria.

Okoli Ifeanyi E., Nnamdi Azikiwe University, Nigeria.

Anugwu Clara Chika, Nnamdi Azikiwe University, Nigeria.

(corresponding e-mail: ifeanyinuel76@gmail.com) creation, capital saving and mobilization, efficiency, strong links with other sectors, use of local technology training for entrepreneurs and self cannot be overemphasized [15]. Since the early 1980s, Nigeria's economic situation has deteriorated seriously. Per capita income falls significantly and wage employment has diminished [25]. The informal sector constitutes a significant segment of the Nigerian economy. In this way, the sector contributes to Gross Domestic Product (GDP) and employment and contributes significantly to Nigeria's economic growth in general [31]. Presently, the sector accounts for more than half of global employment and up to $90 \%$ of employment in some of the poorest developing countries. As a result, according to the International Monetary Fund (IMF), Nigeria's informal sector accounted for $65 \%$ of Nigeria's GDP.

Examining the size of the informal sector, [26] found it difficult to obtain information on the size and structure of employment in the informal sector. [14] citing Peberdy commented that the horrific environmental conditions associated with informal sector activities were unfortunate. This is due to some perennial problems that have affected the development of the sector over the years. These problems that impede the development of this sector in Nigeria range from financial, managerial, marketing, technological, lack of basic physical infrastructure, raw materials and other related problems [6], thus leading to economic crises in the sector.

The economic crisis is not new in Nigeria. During the financial crisis of 2016, the Nigerian monetary authority defended the local currency from the forced devaluation against the dollar and adopted a managed currency exchange system, which worked well from 2016 to 2019. Following the 2016 financial crisis in Nigeria, the sudden and prolonged drop in oil prices is almost believed to have been the most important cause of the recession in Nigeria. But in 2020, no one believed that the public health crisis could trigger a new economic crisis in the country. What made the economic crisis of 2020 different from other economic crises or recession in Nigeria was that most economic actors, who should have helped revive the economy, could not participate in economic activities for fear of being infected by Covid-19 disease [35].

Corona 2019 virus disease (COVID-19) is a disease caused by a new corona virus now called severe acute respiratory syndrome 2 (SARS-CoV-2, formerly called 2019-nCoV), which was first detected in the wake of respiratory illness in Wuhan, Hubei Province, China [9]. A pandemic has been declared by the World Health Organization (WHO) on March 11, 2020. Covid-19 has become a global emergency, given its impact on the entire global population and economy [3]. The crisis is hitting the 
entire world economy, the African economy and most especially the Nigerian economy. A report by the African Union Commission [3] states that in addition to its impact on human health, Covid-19 disrupts an interconnected global economy through global value chains, which account for almost half of global trade, sharply falling prices of goods, tax revenues, foreign exchange receipts, foreign financial flows, travel restrictions, reduction of tourism and hotels, frozen labor market, drastic drop in oil prices, etc. In Nigeria, the Covid-19 crises are crippling the activities of both the formal and informal sectors of the economy with the ensuing economic consequences. In this context, the study investigates the impact of Covid-19 on the economic prospects of the informal sector of Nigeria and the various strategies to sustain the sector.

\section{NATURE OF INFORMAL SECTOR}

Ikeije, Akomolafe \& Onuba [17] emphasized that one of the fundamental problems of policy relating to the informal sector is related to the sector's inappropriate definition. According to [10], certain criteria are used to define the informal sector, such as size, ease of entry, legal status, ownership and management and technology. [8] defines the informal sector as the unregulated segment of the market economy that produces goods and services for sale or for other forms of remuneration.

The International Labor Organization [18] defined the informal sector by employment categories. They thought informal employment was both self-employment and wages that were often not recognized, regulated, or protected by legal or regulatory frameworks. These employment categories include; Self-employment: includes selfemployed workers, family business heads, and unpaid family workers; Wage Workers: Includes informal workers, casual workers without permanent employer, domestic workers, paid domestic workers, temporary and part-time workers, and unregistered workers; and; Employers: Includes owners and owners of informal enterprises. Informal employment mainly refers to employment in companies that have no registration and no social security protection for their employees [27].

Fapohunda [13] found that informal sector is a heterogeneous mix that spans a wide range of economic activities that tend to be ignored in normal statistical economic analysis. These economic activities include manufacturing activities, construction and other services such as the preparation of all types of vehicles, radio and television sets, cooling, hairdressing and carpentry. It is believed that all of these activities, which are often performed in small factories, are owned and operated by one or a few people with minimal capital.

The informal sector, according to [36], refers to all economic activities that do not fall under the official economy. This refers to the general income category (or sector) of the market in which certain types of revenue and means of production are not regulated by the corporate organs, in an environment where similar activities are regulated. [12] views the informal sector as those that often require economic employment activities that exist side by side or partly depend on the modern sector in the urban labor market.

Ojo [29] reveals that informal sectors consist mainly of carpentry, vehicle repairs, other mechanical and electrical enterprises, including watch repairs, ironworks, metallurgy, radio repairs, textile works, including watch repairs, textile companies, including various companies related to sewing and weaving; services such as hairdressing, laundry, photography, etc. and, the retail trade that includes women in the market. Informal sector participants generally live and work under horrific, often dangerous and unhealthy conditions, usually without basic sanitation, in the slums of urban areas [23]. Nonetheless, the informal sector is involved in many challenges despite the sector's contribution to the development of Nigeria's economy. Some of the challenges facing the informal sector include institutional inadequacies, precarious working conditions, poor enforcement, and non-participation of informal entrepreneurs in decision-making.

\section{A. Reasons for the growth of Informal Sector}

The following interrelated and overlapping reasons explain the growth of the informal economy [11], [20], [33]:

1) Limited absorption of excess labor: It has been found that the limited capacity of agriculture and the formal economy to absorb excess labor has increased the size of the informal economy in addition to the increasing number of applicants. In countries like Nigeria, the informal economy tends to absorb most of the excess labor as population growth or urbanization increases, particularly in urban areas.

2) Restrictions on entry into the formal economy: The formal sector in most developing countries is so saturated that new entrants find it difficult to find opportunities. Entry restrictions are often in the form of monopolistic practices by officials in the formal sector.

3) Incapacitation of institutions: The weak ability of formal institutions to provide education, training and infrastructure, as well as other incentives for structural reforms, also contributed to the growth of the informal sector.

4) Redundancies: The structural adjustment programs introduced in Nigeria in 1980s and 1990s appear to have fueled the growth of the informal economy. The observed disappearance of public sector jobs, as well as the closure of non-competitive businesses, forced many laid-off workers to find alternative means of subsistence through the informal economy.

5) Preference of capital over labor: Global integration, encouraging foreign companies to cross borders, has not contributed to the absorption of surplus labor. Integration has consistently benefited capital at work, especially for less skilled workers who find it difficult to immigrate. Thus the informal sector provides another avenue for these calibers of workers to get employment.

6) Demand for low-cost goods and services: Urban migration and the resulting demand for low-cost goods and services from formal and informal companies have also contributed to the growth of the informal economy.

7) Non-committed governments: Many governments in developing economies seem to be unaware of the economic importance of the informal economy and, therefore, have not committed to it. It is often believed that the informal 
economy will eventually disappear. The result is an informal economy with few government barriers to growth.

8) Economic hardship and poverty: Migration from rural cities, mainly due to poverty and lack of public services, has contributed significantly to the development of the informal economy. The lack of adequate mechanisms to help absorb the workforce in the national economy meant that the majority of employment was in the informal economy. This is especially true in developing countries.

\section{COVID-19 AND SituATIONS THAT WORSEN THE CRISIS IN NIGERIA}

The new virus (COVID-19) apparently appeared in Wuhan, China, in late December 2019 and has since spread worldwide, affecting several countries and regions. No continent has been able to escape this virus, which has a mean mortality rate of about $2.3 \%$ (according to [9]). Presently, there have been nearly 450,686 deaths, with more than $8,385,440$ cases confirmed in 215 countries and regions worldwide, showing the seriousness of the virus worldwide [39].

According to scenario simulations of the International Monetary Fund [21], global growth could be reduced by $0.5 \%$ in 2020. Various other sources also predict global growth as a result of the immediate impact of the COVID19 pandemic. The worldwide economy may be in recession at least in the first half of 2020, adding to the immediate and indirect effects of the crisis e.g. supply and demand disruptions, falling goods, declining tourist arrivals, etc., (African Union Commission Report 2020). In Nigeria, however, the effects of COVID-19 are felt in different ways, and situations that contributed to the crisis were different in the areas of focus and fullness.

[24] argue that Nigeria's public health sector has experienced many infrastructural deficits such as poor emergency services, few ambulance services, ineffective health insurance systems, inadequate primary health care and more common health problems are associated with maternal mortality and high infant rates. [7] confirmed that most health care costs in Nigeria are still governed by direct costs, which account for $70 \%$ of total health spending, indicating that most Nigerian health insurers are not recommended or trusted. Despite the launch of the National Health Insurance System (NHIS) in 2004, the population covered by health insurance in 2019 accounted for about 5\% of the total population. This can be attributed to the lack of funds in health insurance [35].

Nigeria's pharmaceutical industry also faces its own problems such as infrastructural inadequacies and unreliable utility services, lack of skilled workers, poor access to finance, lack of adequate government incentives, and disagreement with government officials, poor demand from strong competition from China, the high cost of doing business as a result of imported and expensive production inflows, regulatory problems, among others. Nigeria has an almost unregulated drug market as health services struggle to prevent the importation of illicit drugs and find it difficult to identify informal drug dealers operating without a registered license [16]. The unregulated drug market in Nigeria is the rationale for the spread of poor quality drugs in the country [22]. Failures in Nigeria's public health sector have made it difficult for Nigeria to cope with the rapid spread of Covid-19 disease during the pandemic because quality drugs could no longer be imported into the country due to the closure of borders.

The Nigerian Information and Communication Technology (ICT) are weak. This is evident in most businesses, including banks, schools and tech companies, which operate in the traditional "office work" model as opposed to the "work at home" model [35]. The Corona virus epidemic posed challenges to these businesses in Nigeria. This has affected industries, schools and markets in the short term. The activities of these markets, schools and industries would have been very little affected if they had a large information infrastructure and communication technology.

Ozili [35] believes that before the Covid-19 pandemic, Nigeria had their significant social problems, including child abandonment, armed robbery, homelessness, mental health issues, divorce and single parenting issues. These social problems can only be solved through a serious social protection policy. Unfortunately, the current social protection activities in Nigeria are underdeveloped and underfunded and not available to the majority of those in need [5]. Nigeria does not have a national social protection program that provides assistance to all individuals and families in need, such as health care, food, unemployment benefits, disaster relief and educational assistance. The consequences of the absence of a national protection program became apparent during the corona virus pandemic, as poor citizens could not cope with the economic difficulties.

\section{A. Covid 19: Implications on the Informal Sector}

Nigeria is the largest economy in sub-Saharan Africa and relies heavily on oil as its main source of foreign exchange earnings and government revenue. Following the global financial crisis of 2008-09, the banking sector was effectively recapitalized and regulation improved. Since then, Nigeria's economic growth has been driven by the growth of agriculture, telecommunications and services. Economic diversification and strong growth have not translated into a significant reduction in poverty levels; as more than $62 \%$ of Nigeria's 180 million people still live in extreme poverty [1]. The outbreak of the new corona virus (COVID-19) in China has changed the world tremendously, as it has become a major pandemic and affects millions of people around the globe regardless of geographical location, age, race, gender, etc. etc. While this crisis is primarily a public health issue that has claimed the lives of thousands of people worldwide and is still counting, the economic impact will undoubtedly be overwhelming and likely to lead to major economic crises both in the formal and informal sector [2].

Statistics on the informal sector are unreliable by virtue of the subject, yet they can provide a tentative picture of its relevance (Oluranti, Odunaike \& Jawando, 2015). The Nigerian Ministry of Labour and Productivity is of the view that the informal sector of the nation's economy accounts for no less than $90 \%$ of new job openings in Nigeria [4]. In the same vein, the Lagos office of Federal Ministry of 
Labour declared that the informal sector accounts for 80 per cent of non-agricultural employment, 60 per cent of urban employment and over 90 per cent of new jobs in Nigeria [4]. Arguably, the informal sector constitutes the largest employer of labour and a source of living for many Nigerian. It therefore, contributes significantly to the national economy in terms of employment and income sourcing [38].

Schneider \& Enste [37] opined that the informal sector accounts for 10 to $20 \%$ of world production in developed countries and more than a third of world production in developing countries. The data reported by [20] are the same: $48 \%$ in non-agricultural employment in North Africa, $51 \%$ in Latin America, 65\% in Asia and $72 \%$ in sub-Saharan Africa. The International Labor Organization (ILO) [20] estimates that more than $66 \%$ of total employment in subSaharan Africa is in the informal sector; while in Uganda, about 13.67 million working-age people (14-64 years old) are involved in the informal sector, representing about $98 \%$ of the total working age population. In Nigeria, the Bank of Industry (BoI) has declared the informal sector an important economic factor that contributed to about $65 \%$ of the country's GDP in 2017 [28].

With a pervasive informal sector and outbreak of Covid19, the Nigerian economy is expected to drop drastically. [34] opine that COVID-19 crisis is causing all components of aggregate demand, except for government purchases, to fall in different dimensions. First, the fall in household consumption is as a result of full/partial restrictions on movement, thus causing consumers to spend primarily on essential goods and services. Restrictions on movement not only reduced the consumption of non-basic products in general, but also affected the ability of these groups to generate income, thus reducing their consumer spending. The restrictions on movement have rendered many people jobless, as all economic activities have slowed down. Those that will be most affected are the informal businesses, as small enterprises that may have difficulties adapting to the virtual means of doing business will be left out. Of the unemployed, the worst blow is the daily wage whose livelihoods are based on daily income. Therefore, many people will experience unemployment during this period, and paying bills like house bills, food and school will be almost impossible.

Second, corporate investments will be hurt mainly by the uncertainty that comes with limited knowledge from the pandemic about the duration of the outbreak, the effectiveness of policy measures and the response of economic agents to these measures - as well as negative investor sentiment which are causing a stir in the capital markets of the world. Indeed, the crisis has led to a massive decline in stock prices, as the Nigerian Stock Exchange has recorded its worst performance since the economic crisis of 2008, which eroded investor wealth. Given the plaguerelated uncertainty and negative earnings outlook for potential investment projects, firms may delay long-term investment decisions [34]).

Unfortunately, government acquisitions will increase as governments, which can usually afford to manage budget deficits, utilize fiscal stimulus measures to counteract the decline in consumer spending. However, for commodity- dependent governments, the fall in global demand for goods stemming from the epidemic will significantly increase their fiscal deficit. In Nigeria's case, Brent's crude oil price was just over \$26 a barrel on April 2, while Nigeria's budget assumes \$ 57 a barrel and would still amount to a \$2.18 trillion deficit ( $\$ 6.05$ billion). Similarly, when oil accounts for 90 percent of Nigeria's exports, the fall in oil and oil prices will adversely affect the volume and net export value. Indeed, the steep decline in oil prices associated with the pandemic is forcing the Nigerian government to cut planned spending. [34] reiterated that restrictions on movement of people and closing borders heralded a decline in exports. Already, countries around the world have closed their borders to non-essential movements, and global supply chains have disrupted. Although exports of the least depreciated countries due to falling commodity prices (such as Nigeria) will become cheaper, the limited markets for non-essential goods and services eliminate the expected positive impact on net exports.

\section{STRATEgIES To Sustain THE INFORMAL SECTOR IN THE FACE OF THE COVID-19 CRISIS}

The effects of Covid-19 are felt in various ways and governments around the world are taking action to boost their crippling economies and bring some relief to citizens and businesses more affected by the pandemic. In Nigeria, the informal sector is not left out as different strategies are being planned by policymakers to ensure business sustainability. The Central Bank of Nigeria (CBN) has provided a fiscal stimulus package that includes a credit facility of \#50 billion naira (\$138.89 million) for households and small and medium-sized businesses most affected by the pandemic, a \#100 billion naira loan ( $\$ 277.78$ million) for the health sector and one trillion naira ( $\$ 2.78$ billion) to the manufacturing sector. In addition, interest rates on all CBN interventions have been revised downward from $9 \%$ to $5 \%$, and a one-year moratorium on $\mathrm{CBN}$ intervention facilities implemented as of March 1, 2020.

Despite the fiscal policy intervention aimed at increasing the public health system's ability to provide adequate and affordable health care to those affected by the crisis, it is also important to take into account that the majority of the population is engaged in the informal sector, lack benefits like health insurance and paid holidays. These informal workers in the sector must work daily to survive, so prolonged restriction of movement, even though it is focused on the betterment of people, could cause significant damage. Implementing social protection programs to support employees, especially those in the informal sector is essential.

The federal government's \#50 billion naira fiscal stimulus package can be effectively controlled through the use of social capital mechanisms. This is mainly due to the fact that a large percentage of people in the informal sector do not have a bank account or means of identification, so the use of the bank verification number $(\mathrm{BVN})$ can considerably limit the access to many people in the package. The use of social capital is a key policy instrument which should be used effectively. Government authorities need to understand that the foundations of social capital have a higher margin to 
ensure compliance. There should be collaboration with the state or local governments in this regards. Communities, groups and even markets generally have leaders who can help legitimize government intentions to the vast majority of their followers. In essence, the informal nature does not necessarily equate to disorganization and, therefore, social capital media can be an effective tool for social stability and ensuring that citizens adhere to government restrictions.

The Federal Inland Revenue Service (FIRS) as well as the State Inland Revenue Service (SIRS) will have to waive personal and corporate income tax for people in the informal sector in the second and third quarters of 2020, as the shock has affected the income and profits of households and small businesses, as this will allow the sector to recover from the sharp drop in demand.

\section{REFERENCES}

[1] (2020)

https://theodora.com/wfbcurrent/nigeria/nigeria_economy.html.

[2] (2020). https://nairametrics.com/2020/05/25/new-normal-for-theinformal-sector/.

[3] African Union Commission (2020). Impact of the Corona virus (COVID-19) on the African Economy, Retrieved from https://www.tralac.org/news/article/14483-impact-of-the-coronaviruscovid-19-on-the-african-economy.html accessed on 14th May, 2020.

[4] Ahiuma-Young, V. \& Adeniyi, A. (2008). Informal Sector Accounts for $90 \%$ of New Jobs in Nigeria in Vanguard, September 15, 2008 , Retrieved from http://www.thenigeriabusiness.com/eco207.html. Accessed on 08/05/20.

[5] Ahmed, H. G., Alhassan, S. M., \& Alshammari, F. D. (2017). Social welfare scheme; a neglected component of public health care services in Nigeria. MOJ Public Health, 5(3): 101-104.

[6] Akerele W.O. (1997). "The Effect of Economic Adjustment on Employment in the Urban Information Sector of Ibadan City". NISER Monograph series, 14:22-25.

[7] Aregbeshola, B. S., \& Khan, S. M. (2018). Out-of-pocket payments, catastrophic health expenditure and poverty among households in Nigeria 2010. International Journal of Health Policy and Management, 7(9): 798.

[8] Becker, K. F. (2004). The Informal Economy: A Fact Finding Study, Swedish International Development Cooperation Agency (Sida), Stockholm Sweden.

[9] Chinese Center for Disease Control and Prevention (CDC) (2020). Novel Corona Virus, Wuhan China. Retrieved from https://www.cdc.gov/coronavirus/2019-ncov/about/index.html. accessed on 21/05/2020.

[10] Cole, W. E. \& Fayissa, B. (1991). The urban subsistence Labour force: Toward a policy oriented and empirically accessible taxonomy, World Development, 19 (7): 779-789.

[11] De Soto, H. (2000). "Mystery of Capital: Why Capitalism Triumphs in the West and Fails Everywhere Else", New York: Basic Books.

[12] Fajana, S. (2000). Functioning of the Nigerian Labour Market. YabaLagos, Labofin and Company.

[13] Fapohunda O. J. (1991). "The Urban Informal Sector of Lagos" Centre for Management and Development Journal, 11: 23-36.

[14] Farinmade A. \& Anyankora M. I. (2012). The Challenges of Improving Informal Sector ActivitiesConditions in Lagos Island, Nigeria. British Journal of Arts and Social Sciences, 6(2): 218-232.

[15] Fasanya, I. O. \& Onakoya, A. B. O. (2012). Informal Sector and Employment Generation in Nigeria: An Error Correction Model. Research on Humanities and Social Sciences. 2(7):48-55.

[16] Fatokun, O. (2016). Curbing the circulation of counterfeit medicines in Nigeria. The Lancet, 388(10060), 2603.

[17] Ikeije, U. U., Akomolafe L. \& Onuba C. O. (2016). Labour Practices in the informal sector of Nigerian economy: A critical analysis. Global Journal of Arts, Humanities and Social Sciences, (2):6-14.

[18] International Labour Organisation (ILO) (2003). Scope of the Employment Relationship: Report IV, International Labour Conference, $91^{\text {st }}$ Session, International Labour Office, Geneva.

[19] International Labour Organization (ILO). (1999). Reducing the Decent Work Deficit: A Global Work Agenda to the Circumstances and Realities of the Region, at the 89th Session of the International Labour Conference, Geneva.
[20] International Labour Organization (ILO). (2002). Decent Work and the Informal Economy' at the 90th Session of the International Labour Conference, Report VI, Geneva.

[21] International Monetary Fund (2020). IMF Regional Economic Outlook: Sub-Saharan Africa: COVID-19: An Unprecedented Threat, International Monetary Fund, Washington, DC, Retrieve from https://www.imf.org/en/Publications/REO/SSA/Issues/2020/04/01/sre o0420 accessed on 16/04/2020.

[22] Klantschnig, G., \& Huang, C. (2019). Fake drugs: health, wealth and regulation in Nigeria. Review of African Political Economy, 46(161): 442-458.

[23] Lawanson, B. (2011). Assessment of Home-Based Economic Enterprises in Residential Areas of Lagos Metropolis. An Unpublished PhD Thesis, Federal University of Technology, Akure.

[24] Muhammad, F., Abdulkareem, J. H., \& Chowdhury, A. A. (2017) Major public health problems in Nigeria: A Review. South East Asia Journal of Public Health, 7(1), 6-11.

[25] Nigerian Institute of Social and Economic Research (NISER) (2007). 'Report of baseline study of employment generation in the informal sector of the Nigerian economy'. Prepared by the Nigerian Institute of Social and Economic Research for the Africa Capacity Building Foundation and the ILO. Ibadan: ILO.

[26] Nwaka V. (2005). "The Structure of Nigeria Informal Sector", Journal of Social Science 2:19-42.

[27] OECD (2009). "Is Informal Normal?: Towards More and Better Jobs in Developing Countries", OECD Development Centre Perspective, OECD, Paris.

[28] Ogunde, O. (2019). Nigeria's informal economy: A catalyst for economic growth. Retrieved from https://businessafricaonline.com/nigeria-3/ accessed on 24/04/2020.

[29] Ojo F. (1997). Human Resource Management: Theory and Practice: Panaf publishing, Inc.: Lagos.

[30] Oluranti, S., Odunaike B. A. \& Jawande J. O (2015). Informal economy operators and the challenges of growth in Oyo kingdom, Nigeria.International Journal of Social Sciences and Humanities Reviews, 5(3):162 - 167.

[31] Omisakin I.S. (1999). "Factors influencing success or failure of an enterprise in informal sector" NISER Monograph series No.6:11-54.

[32] Oni-Egboma, A. (2020). Covid-19 and the Informal Economy. Retrieved from https://businessday.ng/news/article/covid-19-and-theinformal-economy/ accessed on 02/05/2020.

[33] Onwe, O. J. (2013). Role of the Informal Sector in Development of the Nigerian Economy: Output and Employment Approach in Journal of Economics and Development Studies. 1(1):60-74.

[34] Onyekwena C. \& Ekeruche M. A. (2020). Understanding the impact of the COVID-19 outbreak on the Nigerian economy. Retrieved from https://www.brookings.edu/blog/africa-infocus/2020/04/08/understanding-the-impact-of-the-covid-19outbreak-on-the-nigerian-economy accessed on 02/05/2020.

[35] Ozili, P.K. (2020). Covid-19 pandemic and economic crisis: The Nigerian experience and structural causes. MPRA Paper No. 99424, 1-12. Retrieved from https://pra.ub.uni-muenchen.de/99424/ accessed on $12 / 05 / 2020$.

[36] Portes A. \& Haller W. (2005). The Informal Economy. The handbook of Economic Sociology $2^{\text {nd }}$ ed. $403-425$.

[37] Schneider, F. \& Enste, D.H. (2000). "Shadow Economics: Size Causes and Consequences" Journal of Economic Literature, 38:77144.

[38] Tamunomiebi M. D. \& Ukachukwu, C. C. (2018). Indecent work and workers in the informal sector in Nigeria. International Journal of Scientific \& Engineering Research, 9(3): 630 - 643.

[39] World Health Organisation (WHO) (2020). Corona virus disease (COVID-2019) situation reports, Retrieved from https://www.who.int/emergencies/diseases/novel-coronavirus2019/situation-reports, accessed on 22/06/2020. 